\title{
Perception of Own Illness and Trust in Medical Personnel among Chronically Ill People
}

\author{
Katarzyna Pawlikowska - Łagód ${ }^{1} \&$ Magdalena Suchodolska ${ }^{2}$ \\ ${ }^{1}$ Cathedral and Department of Humanities and Social Medicine, Medical University of Lublin, Poland \\ ${ }^{2}$ Medical University of Lublin, Poland \\ Correspondence: Katarzyna Pawlikowska - Łagód, Cathedral and Department of Humanities and Social Medicine, \\ Medical University of Lublin, ul. Chodźki 7, 20 - 093 Lublin, Poland
}

Received: April 24, 2021 Accepted: June 15, 2021 Online Published: June 25, 2021

doi:10.5539/gjhs.v13n8p34 URL: https://doi.org/10.5539/gjhs.v13n8p34

\begin{abstract}
Appropriate perceptions of own disease by chronically ill person significantly affects the success of the diagnostic and therapeutic process. It depends on the existential situation of the patient, the adopted strategy of coping with the disease, received social support, as well as on the way the patient is treated by medical personnel. The aim of the conducted research was to assess the relationship between the perception of the disease by chronically ill people and their trust in medical staff.

The study involved 511 people receiving treatment for chronic diseases. The diagnostic survey method was used in the study, the research tools were: the Imagination and Perception of Illness Scale (IPIS), the Brief Illness Perception Questionnaire (Brief IPQ), the Trust in Physician scale by L.A. Anderson and R.F. Dedrick, and a self-authorship questionnaire.

Among the studied population, statistically significant relationships were observed between the perception of own disease by the patient, measured with the IPIS scale, and the trust in medical personnel calculated with the Trust in Physician. In the study group, there are statistically significant differences between the belief of the respondents in the effectiveness of treating their own disease and the overall result of trust in medical personnel.

The perception of own disease by chronically ill people affects the level of trust in medical staff. The way the patients will perceive their illness depends, among other things, on the relationship between them and the doctor.
\end{abstract}

Keywords: trust, trust in a doctor, perception of own disease, chronic disease

\section{Introduction}

A key determinant of therapeutic success is the patient's perception of the nature of the disease (Quiles et al., 2020). The onset of an illness, especially a chronic illness, is always a critical moment in any patient's life. The new situation of the patient is difficult from the emotional, cognitive, social, and existential perspective, as it requires new adaptive skills (Król et al., 2017). The literature on the subject emphasizes that it is an extremely complex process which is influenced by many factors, including: external factors and individual conditions. The first group includes life situation of the patient and the surrounding social support, while the determinants of an individual conditions are beliefs about own disease and its meaning (Nunstedt et al., 2017). Understanding and acceptance of the illness is of great importance in the therapeutic process, recovery and general well-being of the patient, however, depending on the diagnosis and the specificity of the disease, its perception varies (Sak et al., 2014).

The perception of a disease is defined as cognitive and emotional perceptions of the patient about their illness. The perception of illness is not only based on symptoms, but also on the consequences of the disease and the experiences the patient had to face as a result. Patients develop their own ideas about their illness in order to make sense of and adapt to the difficulties the disease causes (Ünal et al., 2019). The patient may have his own thoughts about what is the cause of the disease, how long it will last, how it will affect future life and how it can be controlled or cured (Nur, 2018).

From the point of view of health and clinical psychology, each patient creates an individual picture of the disease, specific to himself, which reflects the current situation of the patient. Patients suffering from the same disease entity may perceive its intensity, configuration, and impact on everyday life in a completely different way. The 
perception of the disease is influenced by personality factors, experiences, relationships with medical staff, other patients, and family (Nunstedt et al., 2017). In the light of the findings of medical sociology, the disease can be understood, as proposed by Parsons (1951), as a social deviation that causes a characteristic type of social disorder (Piątkowski, 2002).

The perception of own illness by the patient depends on his existential situation, strategy of coping with the disease and the received social support, understood in two aspects - structural and functional. With regard to structural support, it is determined by the degree of the patient's involvement within the structure of the social relationship. In addition to the above-mentioned support, emotional support, including from the immediate family, plays an essential role in the perception of own illness. It consists in providing calming and care-reflective emotions during the crisis caused by the illness, as well as in evoking in the patient a sense of belonging, acceptance and increased self-esteem.

The perception of own disease depends not only on the above-mentioned components and on the personality of the ill person, but also on the medical team the patient has been dealing with since the onset of the disease symptoms. The medical staff plays an essential role here, as it is the doctor who tells about the diagnosis, talks to the patient about the disease and proposes appropriate treatment. An individual approach to the patient and the correct transmission of information are key factors in how the patient will perceive his illness. A patient convinced of the possibility of curing and controlling the disease is more likely to cooperate well with medical personnel. The way of perceiving the disease, which can be modified by the level of trust in medical personnel, influences the undertaking of positive health behaviors affecting the therapy and improving patient's health (Sak et al., 2011). Therefore, it is essential for healthcare professionals, and in particular medical personnel, to perceive understanding of the disease by the patient as a primary and necessary source of care (Booker et al., 2008).

The perception of the illness by the patient is not static, it changes over time depending on contextual and cultural factors as well as the physician-patient relationship (Kleinman, 1988). Perception of disease is shaped culturally and as a result of the experiences that an individual acquires during treatment. Moreover, the significance of symptoms and disease varies depending on the ethnic and cultural background of the patient (Good et al., 1981).

So far, only a few studies have been conducted on the associations between trust in medical personnel and perceptions of one's own illness. In contrast, no attempt has been made to identify these relationships only in the group of elderly people. Identifying the associations between elderly people's perceptions of their own illnesses and their level of trust in medical staff may contribute to the develompent of knowledge regarding the psychosocial aspects of elderly people's functioning in a situation of illness. When the elderly entrust their health to a doctor, they expect the doctor to be adequately involved in their treatment process and to understand their needs and expectations. On the other hand, there have been studies on the relationship between trust in medical personnel and the perception of one's own illness among people under the age of 60. In this study, the authors focused on comparing the relationship between self-perception of illness and trust in medical staff in the above-mentioned groups. The aim was to see differences in the perception of illness and trust in medical staff. To increase interest in the study, the authors compared the relationships between self-perception of illness and trust in medical staff among elderly people who had been hospitalized for a specific illness versus those under 60 years of age who were treated on an outpatient basis.

The purpose of this study was to assess how trust in medical personnel affects hospitalized and outpatient patients perceptions of their own illnesses.

\section{Method}

\subsection{Participant (Subject) Characteristics}

The cross-sectional study was conducted between June 2018 and January 2019. It involved 511 people treated for a specific chronic disease. One group consisted of 303 people over 60 years of age who were hospitalized due to a specific disease in Lublin hospitals, the other group consisted of 208 people between 45 and 59 years of age receiving outpatient treatment in primary healthcare centres in Poland. In selection of the population a non-random-purposive scheme was used.

The research procedure was started after obtaining a positive opinion of the Bioethics Committee at the Medical University of Lublin (KE-0254/109/2016). The following research tools were used in the study: Imagination and Perception of Illness Scale (IPIS), Brief Illness Perception Questionnaire (Brief IPQ), Trust in Physician scale by L.A. Anderson and R.F. Dedrick, self-authorship questionnaire.

The IPIS questionnaire constructed by J. Sak (2013) refers to the semantic differential technique. It consists of 32 opposing terms concerning the perception of disease. In previous studies, the following components of the IPIS 
scale were distinguished: loss of motivation for targeted activities ( 8 items), destruction of the psychical sphere (6 items), destruction of the physical sphere ( 8 items), pessimism (4 items), reactions to their surroundings as caused by their disease ( 3 items) and their loss of control over it ( 3 items). As a result of a different number of individual components, the obtained results are expressed as the arithmetic mean calculated separately for each of the six indicators. Respondents put their answers on a seven-step scale, where " 0 " means the choice of the maximally positive item attributed to the disease and the number " 6 " signifies the opposite. The higher score obtained within a given IPIS dimension, the more negative the perception on the disease through the prism of this factor (Sak, 2014). The reliability of the above Scale was determined by $\alpha$-Cronbach's coefficient, which exceeded the value of 0.7. The tool can be used both among sick people in relation to their subjectively perceived illness as well as healthy people to examine perceptions of particular disease entities (Sak, 2013).

The Trust in Physician scale by Anderson and Dedrick is a five-point scale consisting of 11 statements about trust in the doctor-patient relationship. It focuses on trust in the doctor's reliability, knowledge, and skills he acquired, as well as maintaining confidentiality and integrity (Anderson \& Dedrick, 1990). While responding to the given statements, the respondents put their answers on the five-point Likert Scale, where "1" means "strongly disagree", and " 5 " means "strongly agree". The analysis of the results should be performed by calculating the percentage values and mean values of points obtained on the basis of the answers to each of the questions (Krajewska - Kulak et al., 2011). The higher the score obtained by the patient on this scale, the greater the trust in the medical staff. The reliability and validity of the scale has been confirmed, with a $\alpha$-Cronbach's coefficient of 0.90 (Anderson \& Dedrick, 1990).

The Brief Illness Perception Questionnaire (Brief IPQ) was constructed by Broadbent, Petrie, Main and Weinman (2006). The main purpose of this questionnaire is to assess the cognitive and emotional perceptions of the disease. The questionnaire consists of eight closed questions and one open question (Broadbent et al., 2006). The respondents place the answers to these questions on the Likert Scale from 0 (minimum) to 10 (maximum). The higher the patient's score, the stronger the support for that item on the scale. The obtained results are presented using the arithmetic mean. The questionnaire has been translated into 36 languages. It is designed for use in groups rather than individuals (Basuautor \& Poole, 2016). The authors of the questionnaire assessed its reliability using a retest among 132 outpatients. The authors of the questionnaire assessed its reliability using a retest among 132 outpatients and as a result the good retest reliability was demonstrated (Pearson correlations 0.24-0.73). The equivalent short IPQ and IPQ-R scales had moderate to good correlations when tested for simultaneity (Pearson correlations 0.32-0.63) (Broadbent et al., 2006). The discriminative accuracy of the questionnaire was confirmed by its ability to discriminate between different diseases, namely asthma, diabetes, cold, myocardial infarction before hospital discharge, and predisposition of patients with chest pain awaiting exercise testing (Siong, 2012). The results obtained are presented using the arithmetic mean.

The self-authorship questionnaire concerned questions relating to socio-demographic issues: age, sex, place of residence, education.

\subsection{Statistical Analysis Methods Used}

After analyzing the distribution of the controlled dependent variables, it was found that these distributions differ statistically significantly from normal distributions. As a result, non-parametric tests were used to analyze the obtained data. The Mann Whitney $U$ test was used for comparisons between the two groupshe correlations between the controlled variables expressed in quantitative scales were investigated using the Spearman's rank correlation coefficient - rho. The range of statistical significance was $p<0.05$, and $p$ values between 0.05 and 0.01 were interpreted as statistical trends. All statistical analyzes were performed using Statistica, version 12.5.192.0 PL (StatSoft Inc., Poland).

\subsection{Characteristics of the Study Group}

The study involved 511 people, of whom one group consisted of 303 people over 60 years of age who were hospitalized due to a specific disease, and the other group consisted of 208 people between 45 and 59 years of age receiving outpatient treatment.

For the group of hospitalized patients, the inclusion and exclusion criteria were as follows:

Inclusion Criteria:

1). Individuals who were 60 years of age or older.

2). Individuals who have been hospitalized for a specific chronic disease at least once during the 12 months prior to the study. 
3). Individuals who gave informed consent to participate in the study.

Exclusion criteria:

1). Individuals who were under 60 years of age.

2). Individuals declaring that they did not have any chronic diseases.

3). Individuals who did not agree to participate in the study.

For the outpatient group, the inclusion and exclusion criteria are as follows:

Inclusion criteria for the control group:

1). Individuals who were in the age range of $45-59$ years.

2). Individuals undergoing treatment for a specified chronic disease in an outpatient setting.

3). Individuals who gave informed consent to participate in the study.

Exclusion criteria for the control group:

1). Individuals outside the age range of $45-59$ years.

2). No history of chronic disease.

3). Individuals who did not agree to participate in the study.

Women constituted $52.05 \%(\mathrm{~N}-266)$, men $47.95 \%(\mathrm{~N}-245)$. The average age was 62.2 years $(\mathrm{SD}=8.77)$. The main place of residence of the respondents was the city: $73.97 \%(\mathrm{~N}-378), 26.03 \%$ came from the village $(\mathrm{N}-133)$. The most numerous group were married people - 47.55\% (N - 243) and widowed - 20.16\% (N - 103). In terms of the level of education, the respondents declared secondary education - 37.96\% (N-194), vocational education $29.55 \%(\mathrm{~N}-151)$ and higher education $-29.16 \%(\mathrm{~N}-149)$. Almost half of the respondents $(45.99 \%)$ assessed their health as average. Only $23.29 \%$ rated it as good, and $1.37 \%$ as very good.

Among the group of hospitalized patients, the most common disease was diabetes mellitus (12.54\%), ischemic heart disease (11.22\%) and myocardial infarction (9.90\%). In the group of outpatients, diabetes mellitus (9.13\%), hypertension (8.65\%) and pneumonia $(8.17 \%)$.

\section{Result}

To address the main objective of this study, we first calculated separately for each group the level of trust in the medical staff using the Trust in Physician scale by Anderson and Dedrick and the perception of one's own illness as measured by the IPIS and Brief IPQ scales. Then it was calculated how trust in the medical staff affects the perception of own illness among inpatients and outpatients.

In the group of hospitalized people (table 1), statistically significant relationships were observed between the perception of own disease, measured with the IPIS scale and trust in medical staff calculated using the Trust in Physician scale by Anderson and Dedrick. These correlations are visible in relation to the following components: loss of motivation for targeted activity: $\mathrm{p}-0.0001$, mental sphere destruction: $\mathrm{p}-0.007$, physical sphere destruction: $\mathrm{p}-0.002$, pessimism: $\mathrm{p}-0.001$ and loss of control over the illness: $\mathrm{p}-0.001$.

Table 1. Relationships between self-perceived illness as measured by the IPIS scale and trust in medical staff as calculated by the Trust in Physician scale by Anderson and Dedrick for a group of hospilitalized patients

\begin{tabular}{|c|c|c|}
\hline \multicolumn{3}{|l|}{ Group of hospitalized people } \\
\hline \multirow{2}{*}{ IPIS scale factors } & \multicolumn{2}{|c|}{ Trust_AD_Overall score } \\
\hline & R (rho) & $\mathrm{P}$ \\
\hline Loss of motivation for targeted activity & $-0,22$ & $0,0001 *$ \\
\hline Mental sphere destruction & $-0,16$ & $0,007 *$ \\
\hline Physical sphere destruction & $-0,17$ & $0,002 *$ \\
\hline Pessimism & $-0,18$ & $0,001 *$ \\
\hline Being a burden to others & 0,04 & 0,522 \\
\hline Loss of control over the illness & $-0,19$ & $0,001 *$ \\
\hline
\end{tabular}

$* \mathrm{p}<0.05$. 
In the group of outpatients (Table 2), statistically significant relationships were also observed between the perception of own disease measured with the IPIS scale and the trust in medical staff calculated using the Trust in Physician scale by Anderson and Dedrick, in the following components: physical sphere destruction: $\mathrm{p}-0.003$ and being a burden to others: $\mathrm{p}-0.0001$.

Table 2. Relationships between self-perceived illness as measured by the IPIS scale and trust in medical staff as calculated by the Trust in Physician scale by Anderson and Dedrick in a group receiving outpatient treatment.

\begin{tabular}{lcc}
\hline Group receiving outpatient treatment & \multicolumn{2}{c}{ Trust_AD_Overall score } \\
\hline \multirow{2}{*}{ IPIS scale factors } & $\mathrm{R}($ rho $)$ & $\mathrm{P}$ \\
\cline { 2 - 3 } & 0,02 & 0,791 \\
Loss of motivation for targeted activity & $-0,05$ & 0,442 \\
Mental sphere destruction & 0,20 & $0,003^{*}$ \\
Physical sphere destruction & $-0,02$ & 0,731 \\
Pessimism & $-0,27$ & $0,0001^{*}$ \\
Being a burden to others & $-0,03$ & 0,697 \\
Loss of control over the illness &
\end{tabular}

$* \mathrm{p}<0.05$.

In the group of hospitalized people, there are statistically significant differences ( $p-0.029)$ between the respondents' belief in the effectiveness of treatment of their own illness and the overall result of trust in medical personnel measured using the Trust in Physician scale by Anderson and Dedrick (table 3).

Table 3. Differences between self-perception of illness as measured by the Brief-IPQ and trust in medical staff among hospitalized patients.

\begin{tabular}{lcc}
\hline Group of hospitalized people & \multicolumn{2}{c}{ Trust_AD_Overall score } \\
\hline \multirow{2}{*}{ Brief-IPQ item } & $\mathrm{R}($ rho $)$ & $\mathrm{P}$ \\
\cline { 2 - 3 } & $-0,03$ & 0,612 \\
Consequences (IPQ 1) & $-0,04$ & 0,502 \\
Timeline (IPQ 2) & 0,09 & 0,122 \\
Personal control (IPQ 3) & 0,13 & $0,029^{*}$ \\
Treatment control (IPQ 4) & $-0,05$ & 0,416 \\
Identity (IPQ 5) & $-0,06$ & 0,269 \\
Concern (IPQ 6) & 0,03 & 0,585 \\
Understanding (IPQ 7) & $-0,04$ & 0,499 \\
Emotional response (IPQ 8) & & \\
\hline
\end{tabular}

${ }^{*} \mathrm{p}<0.05$. 
Table 4. Differences between self-perceived illness as measured by the Brief-IPQ and trust in medical staff among outpatients

\begin{tabular}{lcc}
\hline Group receiving outpatient treatment & \multicolumn{2}{c}{ Trust_AD_Overall score } \\
\hline \multirow{2}{*}{ Brief-IPQ item } & $\mathrm{R}($ rho $)$ & $\mathrm{p}$ \\
\cline { 2 - 3 } & $-0,05$ & 0,439 \\
\hline Consequences (IPQ 1) & $-0,08$ & 0,269 \\
Timeline (IPQ 2) & 0,01 & 0,878 \\
Personal control (IPQ 3) & 0,06 & 0,357 \\
Treatment control (IPQ 4) & $-0,02$ & 0,726 \\
Identity (IPQ 5) & $-0,16$ & $0,024^{*}$ \\
Concern (IPQ 6) & 0,02 & 0,754 \\
Understanding (IPQ 7) & $-0,03$ & 0,621 \\
Emotional response (IPQ 8) & &
\end{tabular}

$* \mathrm{p}<0.05$.

\section{Discussion}

Establishing a link between the perception of own illness and trust in medical personnel is an important part of both clinical medicine and public health. The perception of the disease, its understanding and acceptance should depend not only on the patient but also on the doctor. How the doctor will treat the patient (especially in old age) whether he treats him with respect, autonomy and intimacy, adequate to age and mental state, determines the patient's perception of the illness and his level of trust in the doctor.

The literature on this topic is, unfortunately, quite limited. Most often, authors in their analyses focus separately on trust in medical personnel and perception of patients of their diseases. So far, few studies have been conducted to discuss the relationship between these relationships. One of them was a study of oncological patients in the UK. The studies show that belief in the treatment process, understanding of the disease and its low harmful impact on life were strong predictors of trust in medical personnel (Lord et al., 2012). In addition, Bell (2013) referred in their research not to the chronicity of the disease or its impact on the emotional state of the patient, but to the way the number of chronic diseases in the elderly affects trust in the doctor. The results they obtained show that with the increasing number of these diseases the trust in medical personnel decreases (Bell et al., 2013). This may be due to the fact that there is still a shortage of doctors specialized in geriatrics and the senior is forced to undergo treatment by several specialist doctors. Consequently, this may result in conflicting information about the diagnosis and the therapeutic process. Gabay (2015) was one of the few authors who referred to the impact of controlling one's health on the level of trust in a doctor. The analysis of the results of his research allowed for the conclusion that controlling one's own health significantly influences the trust in medical personnel (Gabay, 2015). AlRuthia (2020), in their analysis of diabetes patients treated in primary healthcare centres, examined the relationship between the physical, psychological, social and environmental HRQoL domains and patients' trust in primary care physicians. The results of their research indicate that the positive relationship between trust and HRQoL identified in their analysis does not support the notion that any degree of trust would impair health outcomes. However, the authors suggest that more research should be done specifically on this issue to obtain a definitive answer (AlRuthia et al., 2020).

The results of our study show that there is a relationship between the perception of one's own illness and trust in the medical staff. This is demonstrated, among other things, by the fact that the level of trust in the medical personnel significantly influenced the perception of illness, which was measured using the IPIS scale among elderly, hospitalized patients. Hospitalized patients who had a low level of trust in the medical staff showed a negative perception of their own illness, including destruction of the mental and physical spheres. Moreover, the lower the trust in physicians, the less motivated the seniors were to overcome their illness. For outpatients, on the other hand, the findings were somewhat different. The differences in the above results may be due to the fact that in primary care, the medical staff can devote more time to patients, focus on them, and, above all, maintain adequate intimacy. During hospital treatment, on the other hand, an individual approach to the patient is often missing. Test results and further treatment are discussed among all patients in the ward, which may not be comfortable for many, 
especially seniors. In addition, physicians working on hospital wards are overburdened with many responsibilities, which has an impact on the short time available for discussions with patients. These phenomena and behaviors contribute to a lack of trust towards medical staff.

\section{Conclusions}

The perception of own disease by chronically ill people affects the level of trust in medical staff. The way a patient will perceive his illness depends, among other things, on the relationship between him and the doctor. This issue also determines the level of trust in the physician.

Unfortunately, at present, the literature on the perception of one's own illness and trust in medical staff is quite limited. Most of the authors have focused separately on the above issues. Our own research has only presented an outline of the problem of the influence of the perception of one's own illness on the level of trust in medical personnel. Nevertheless, dependencies were observed, inter alia, between worrying about your own disease, the effectiveness of treatment and the destruction of the physical sphere, and trusting doctors. It does not change the fact that further analyzes on the discussed topic are needed.

\section{Competing Interests Statement}

The authors declare that there are no competing or potential conflicts of interest.

\section{References}

Adamska, M., Juczyńska, K., \& Miniszewska, J. (2015). Sposób postrzegania własnej choroby jako czynnik wyznaczający jej akceptację u osób chorych na łuszczycę. Curr Probl Psychiatry, 16(1), 26-37.

AlRuthia, Y., Sales, I., Almalag, H., Alwhaibi, M., Almosabhi, L., Albassamm, A. A., ... \& Asiri Y. (2020). The Relationship Between Health-Related Quality of Life and Trust in Primary Care Physicians Among Patients with Diabetes. Clin Epidemiol., 12, 143-151. https://doi.org/10.2147/CLEP.S236952

Anderson, L. A., \& Dedrick, R. F. (1990). Development of the in Physician scale: a measure to assess interpersonal trust in patient-physician relationships. Psychol Rep, 67, 1091-1100. https://doi.org/10.2466/pr0.1990.67.3f.1091

Basuautor. S., \& Poole, J. (2016). The Brief Illness Perception Questionnaire. Occupational Medicine, 66(5), 419-420. https://doi.org/10.1093/occmed/kqv203

Bell, R. A., Arcury, T. A., Ip, E., Grzywacz, J. G., Nguyen, H., Kirk, J. K., .. \& Quandt, S. A. (2013). Correlates of Physician Trust Among Rural Older Adults with Diabetes. Am J Health Behav, 37(5), 660-666. https://doi.org/10.5993/AJHB.37.5.10

Booker, S., Morris, M., \& Johnson, A. (2008). Entitlement to Change: Evidence from a Qualitative Analysis of an Information-Based Psychoeducational Program for People with Type 1 Diabetes. Chronic Illn., 4(1), 41-53. https://doi.org/10.1177/1742395307086695

Broadbent, E., Petrie, K. J., Main, J., \& Weinman, J. (2006). The brief illness perception questionnaire. $J$ Psychosom Res., 60, 631-637. https://doi.org/10.1016/j.jpsychores.2005.10.020

Gabay, G. (2015). Perceived control over health, communication and patient-physician trust. Patient Education and Counseling, 98(12), 1550-1557. https://doi.org/10.1016/j.pec.2015.06.019

Good, B. J., Good, M. J., Eisenberg, L., \& Kleinman, A. (1981). The relevance of social science for medicine. Netherland: Springer.

Kleinman, A. (1988). Narracje dotyczace choroby. Cierpienie, uzdrowienie i stan ludzki. New York: Basic Books.

Krajewska-Kułak, E., Chilicka, M., Kułak, W., Adraniotis, J., Chadzopulu, A., \& Rozwadowska, E. (2011). Assessment of physician-patient trust in the obstetrics and gynecology departments in Poland and Greece, Ginekol Pol., 82, 905-910.

Król, J., Koziarska, D., Rzepa, T., Szcześniak, M., \& Nowacki, P. (2017). Percepcja własnej choroby przez osoby z rzutowo- remisyjną postacią stwardnienia rozsianego (SMRR)- doniesienie wstępne. Adv Psychiatry Neurol, 26(1), 24-35. https://doi.org/10.5114/ppn.2017.68292

Lord, K., Ibrahim, K., Kumar, S., Rudd, N., Mitchell, A. J., \& Symonds, P. (2012). Measuring trust in healthcare professionals--a study of ethnically diverse UK cancer patients. Clin Oncol (R Coll Radiol), 24(1), 13-21. https://doi.org/10.1016/j.clon.2011.05.010

Nowakowski, M. (2004). Pojęcie wsparcia społecznego i problemy jego pomiaru ze szczególnym uwzględnieniem 
populacji seniorów. In J. T. Kowaleski, \& P. Szukalski, P. (red.), Nasze starzejące się społeczeństwo. Nadzieje i zagrożenia (pp. 292-300), Wyd. Uniwersytetu Łódzkiego, Łódź.

Nunstedt, H., Rudolfsson, G., Alsen, P., Alsen, P., \& Pennbrant, S. (2017). Patients' Variations of Reflection About and Understanding of Long-Term Illness- Impact of Illness Perception on Trust in Oneself or Others. Open Nurs J., 11, 43-53. https://doi.org/10.2174/1874434601711010043

Nur, K. R. M. (2018). Illness perception and cardiovascular health behaviour among persons with ischemic heart disease in Indonesia. Int J Nurs Sci., 10, 5(2), 174-180. https://doi.org/10.1016/j.ijnss.2018.04.007

Piątkowski, W. (2002). Choroba jako zjawisko socjologiczne, Wprowadzenie do wybranych koncepcji badawczych, Zdrowie i choroba, Wybrane problemy socjologii medycyny, Barański, J., Piątkowski, W. (red.), Oficyna Wydawnicza ATUT Wrocławskie Wydawnictwo Oświatowe, Wrocław.

Quiles, Y., José Quiles, M., León, E., \& Manchon, J. (2020). Illness Perception in Adolescent Patients With Anorexia: Does It Play a Role in socio-emotional and Academic Adjustment? Front Psychol., 11, 1730. https://doi.org/10.3389/fpsyg.2020.01730

Sak, J. (2013). Wielowymiarowość postrzegania choroby w kontekście przekonań zdrowotnych i poczucia sensu życia. Rozprawa habilitacyjna. Uniwersytet Medyczny w Lublinie 2013.

Sak, J., Dryl-Rydzyńska, T., \& Książek, A. (2014). Relationships between perception of illness, social support and hemodialysis adequacy. Pol J Public Health, 124(4), 174 - 177. https://doi.org/10.1515/pjph-2015-0002

Sak, J., Jarosz, J. M., Mosiewicz, J., Sagan, D., Wiechetek, M., Pawlikowski, J., \& Olszewska, E. (2011). Postrzeganie własnej choroby a poczucie odpowiedzialności za swoje zdrowie osób przewlekle chorych. Medycyna Ogólna i Nauk o Zdrowiu, 17(4), 169-173.

Siong, Ng. T. (2012). Brief Illness Perception Questionnaire (Brief IPQ). Journal of Physiotherapy, 58(3), 202. https://doi.org/10.1016/S1836-9553(12)70116-9

Ünal, Ö., Akyol, Y., Tander, B., Ulus, Y., Terzi, Y., \& Kuru, Ö. (2019). The relationship of illness perceptions with demographic features, pain severity, functional capacity, disability, depression, and quality of life in patients with chronic low back pain. Turk $J$ Phys Med Rehabil., 65(4), 301-308. https://doi.org/10.5606/tftrd.2019.3248

\section{Copyrights}

Copyright for this article is retained by the author(s), with first publication rights granted to the journal.

This is an open-access article distributed under the terms and conditions of the Creative Commons Attribution license (http://creativecommons.org/licenses/by/4.0/). 